\title{
小型パルス中性子源のための中性子計測法の最近の進展
}

\author{
有川 安信 ${ }^{1}$, 池田 裕二郎 ${ }^{2}$, 清水 裕彦 $^{3}$, 花山 良平 ${ }^{4}$, 近藤 治靖 ${ }^{5}$, 黒澤 俊介 $^{6,7}$ \\ ${ }^{1}$ 大阪大学レーザー科学研究所 († 565-0871 大阪府吹田市山田丘2-6) \\ ${ }^{2}$ J-PARC ( ₹319-1195 茨城県那珂郡東海村大字白方2番地4) \\ 名古屋大学 ( \\ ${ }^{4}$ 光産業創成大学院大学 ( T431-1202 静岡県浜松市西区呉松町1955-1) \\ 5浜松ホトニクス株式会社( ₹434-8601 静岡県浜松市浜北区平口5000) \\ ${ }^{6}$ 東北大学 ( $7980-8577$ 宮城県仙台市青葉区片平2-1-1) \\ ${ }^{7}$ 山形大学 (
}

\section{Recent Development of Neutron Detectors for Pulsed Compact Neutron Sources}

\author{
Yasunobu ARIKAWA, ${ }^{1}$ Yujiro IKEDA, ${ }^{2}$ Hirohiko M. SHIMIZU, ${ }^{3}$ Ryohei HANAYAMA, ${ }^{4}$ \\ Haruyasu KONDO, ${ }^{5}$ and Shunsuke KUROSAWA ${ }^{6,7}$ \\ ${ }^{1}$ Institute of Laser Engineering, Osaka University, 2-6 Yamadaoka Suita, Osaka 565-0871 \\ ${ }^{2}$ J-PARC, 2-4 Oaza shirakata Tokaimura Nakagun, Ibaraki 319-1195 \\ ${ }^{3}$ Nagoya University, Furocho, Chikusa, Nagoya 464-8602 \\ ${ }^{4}$ The Graduated school for photon industory, 1-1955 Kurematsu Nishiku Hamamatsu, Shizuoka 431-1202 \\ ${ }^{5}$ HAMAMATSU PHOTONICS K.K., 5000 Hirakuchi, Hamakita-ku, Hamamatsu, Shizuoka 434-8601 \\ ${ }^{6}$ Tohoku University, 2-1-1 Katahira, Aobaku, Sendai, Miyagi 980-8577 \\ ${ }^{7}$ Yamagata University, 4-12-1 Koshirakawa, Yamagata 990-8560
}

(Received July 7, 2018)

\begin{abstract}
Compact neutron sources have been used as a various diagnostics such as neutron diffraction, neutron resonant analysis, and neutron radiography. The developments of the neutron detectors are essential for all of these applications, while the techniques are strongly dependent on the neutron energy and the aim of the measurement. This paper reviews neutron detection techniques pertinent to promote compact neutron source uses. Along with general neutron detection systems with conventional counters for slow neutrons, we have highlighted detectors for high energy neutrons with high time resolution and high sensitivity which could be applied in a laser-driven compact neutron source.
\end{abstract}

Key Words: Neutron diagnostics, Scintillator, Activation measurement

\section{1. はじめに}

小型パルス中性子源の開発 ${ }^{1-3)}$ は急速に進んでいる. 小型中性子源は, 中性子ラジオグラフによる非破壊検 査 ${ }^{4)}$, 中性子回折を用いた物質の構造解析 ${ }^{5)}$, 中性子共 鳴吸収を利用した金属材料の元素分析6), BNCT (Boron Neutron Capture Therapy $)^{7)}$ に代表される中性子医療など， 広範囲の利用で期待されている。 どの利用においても, 中性子フラックス, エネルギースペクトル, 中性子によ る画像計測技術はその研究の根幹をなす。中性子はその エネルギーによって適用可能な計測手法はさまざまであ り, 感度・時間応答 - 画像計測をする場合の空間分解能 の特徵は計測手法ごとに大きく異なる，本稿では中性子 計測技術開発とその基盤技術を，特に画像計測をするこ とを念頭に置いた観点から, 熱中性子領域, エピサーマ
ルから中間領域エネルギー, 高速中性子に分けてレ ビューする. 特に, 最近進展の目覚しいレーザー駆動中 性子源開発で重要な短パルス高輝度中性子源で活躍が期 待される計測技術を展望する。

\section{2. 熱中性子計測技術}

中性子応用の中で最も歴史が長く，応用も多いのが熱 中性子(室温の運動エネルギーを持つ中性子, $0.025 \mathrm{eV}$ 付近を言う)である。熱中性子領域(ここでは0.025 eVか ら0.5 eVと定義)の計測は, 中性子捕獲反応によって中 性子を捕獲し, 発熱反応で荷電粒子を放出するいくつか の反応に限定される。 Fig. 1 に, 低エネルギー中性子計 測で用いられる代表的な元素の反応断面積を示す．断面 積はJENDLデータベース ${ }^{8)}$ を用いた. 水素の散乱反応 


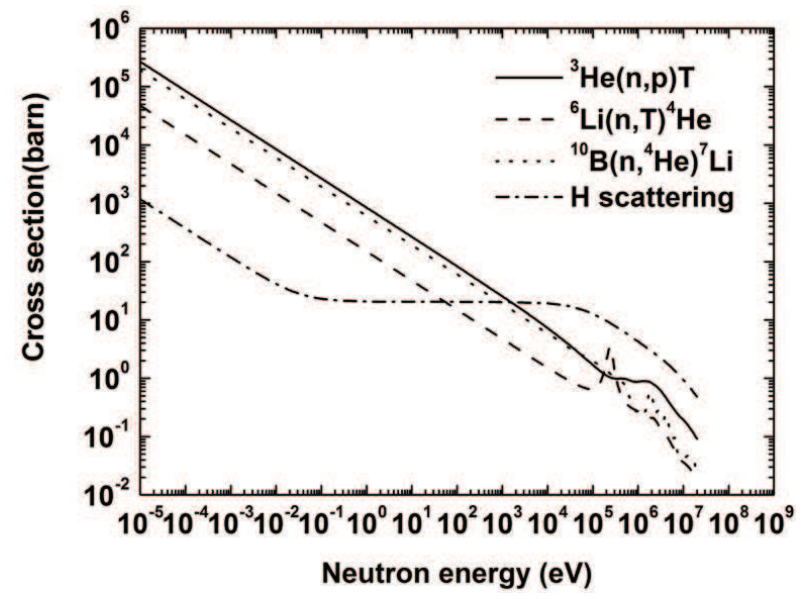

Fig. 1 Neutron reaction cross sections for thermal neutron detection.

は, 高エネルギーの中性子に対しては反跳(リコイル)に 対応し, 主に高速中性子計測で用いられる。 ${ }^{3} \mathrm{He}$ に中性 子が吸収されると陽子とトリトン $(\mathrm{T})$ を放出し, その電 離をもちいた比例計数管が中性子検出に用いられる 熱中性子領域に吸収断面積が非常に高く, 一般的な ${ }^{3} \mathrm{He}$ ガス比例計数管はほぼ100\%の効率で中性子を検出する ことができる。この装置はガス管からなる装置であ り, 0次元検出器 (フラックスモニター)として用いられ るほか, 抵抗分割読み出しによる1次元検出器として用 いられる。 ${ }^{3} \mathrm{He}$ をンバーターとするガス検出器には, マルチワイヤー比例計数管 (MWPC)，またはマイクロ パターン読み出しのドリフト検出器などいくかのタイプ があり，2次元検出器として用いられる。マイクロパ ターンの検出器については, 参考文献10)に特徵がまと められている。ママイクロパターン読み出しのドリフト検 出器は高い計数率で利用でき, 飛跡を解析することで高 い位置分解能を達成できる。近年では, マイクロピクセ ルカウンター $(\mu-\mathrm{PIC})$ 装置で100 $\mu \mathrm{m}$ の空間分解能が得ら れており, 中性子イメージングの応用が急速に広がって いる ${ }^{11)}$. 比例計数管の立ち上がり時間は熱中性子や冷中 性子の飛行時間計測に用いるのに十分な程早い. Gas Electron Multiplier (GEM) は高い計数率( 数百 $\mathrm{kHz}$ ) と位 置分解能 $(\sim 1 \mathrm{~mm})^{12}$ を比較的単純な読み出し系で実現 する柔軟性の高い検出器である。さらにGEM検出器の 電極に ${ }^{10} \mathrm{~B}$ をつて, $\mathrm{B}(\mathrm{n}, \alpha)$ 反応によって生じる $\alpha$ 粒子 を検出する夕イプの2次元検出器として開発が進んでい る ${ }^{12)}$ 。また ${ }^{10} \mathrm{~B}$ を用いた材料で作られたマイクロチャン ネルプレートによる画像検出装置は非常に優れた空間分 解能 $(55 \mu \mathrm{m})$ を実現している ${ }^{13)}$. 中性子イメージインテ ンシファイアとよばれる, ガドリニウムドープシンチ レーターを中性子コンバーターとして用いたフォトカ ソードと電子加速管からなり, 中性子画像を可視画像に するデバイスも知られている ${ }^{14)}$. ${ }^{6} \mathrm{Li}$ は固体で存在し, 化合物にすると結晶やガラスにすることもできるため, シンチレーター材料として有用である。中性子散乱実験 において広く用いられてきたものは年抽/ $\mathrm{ZnS}(\mathrm{Ag})$ であ る ${ }^{15)}$. この材料は不透明であるため, 位置敏感型光電子
増倍管の光電空上に薄い ${ }^{6} \mathrm{LiF} / \mathrm{ZnS}(\mathrm{Ag})$ 板を密着させて, 中性子画像計測として用いらている ${ }^{16)}$ 。 ${ }^{6} \mathrm{LiF} / \mathrm{ZnS}(\mathrm{Ag})$ は 発光量が大きい $(100,000$ photons $)$ という利点があるが, 発光の減衰時間が長く(蛍光寿命 $2 \mu \mathrm{s}$ ) 検出効率を高くす ることが難しい. より高速応答のシンチレーターとし

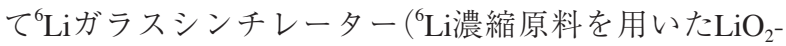
$\mathrm{SiO}_{2}$ のガラスにCeが添加されたもの)がある。またピク セル化したLiガラスシンチレーターをマルチアノード光

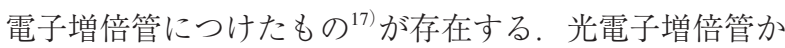
ら直接読み出しを行うことで最大 $28 \mathrm{MHz}$ ま゙の超高速 読み出しが実現している。空間分解能はマルチアノード 光電子増倍管のピクセルサイズである $2 \mathrm{~mm}$ 程度に制限 される。重心計算解析によって分解能が $1 \mathrm{~mm}$ 程度まで 向上する技術も知られている ${ }^{18)}$ 。これらピクセル系装置 とGEMについては ${ }^{19)} に$ 最近の進展がまとめられている.

Li系シンチレーターの近年の進展としては, 従来のガ ラスシンチレーターよりも発光減衰が早くまた高速応答 な結晶シンチレーターとして, $\operatorname{LiCAF}\left(\mathrm{Eu}^{2+}: \mathrm{LiCaAlF}_{6}\right.$, $\left.\mathrm{Ce}^{3+}: \mathrm{LiCaAlF}_{6}\right)$ が登場している ${ }^{20)}$ 。これらは固体密度 の10\%程度の数密度で $\mathrm{Li}^{\circ}$ 含んでおり, $1 \mathrm{~mm}$ 厚や $100 \mu \mathrm{m}$ 粉末状態でも熱中性子に対してほぼ100\%の検出 効率を出すことができる。粉末にして透明材料に塗布す れば中性子画像計測用シンチレーターパネルとなり， シ ンチレーター発光画像を高感度カメラでとらえる中性子 画像装置として期待できる. 時間分解能はLiガラスシン チレーターは60 ns 程度, Ce:LiCAFは20 ns 程度であり, その他著者らのグループでは既存のシンチレーターと比 ベて高速応答 (減衰時定数 $5 \mathrm{~ns}$ ) の ${ }^{6} \mathrm{Li}$ ガラスシンチレー ターAPLF80 ${ }^{21)}$ を開発した。 シンチレーション発光効率 をさらにたかめる試みとして, 発光量とバンドギャップ エネルギーは反比例の関係にあることから, 小さい バンドギャップエネルギーを持つ塩化物や臭化物などに 注目した材料探索が米国などを中心に行われている. 具体的には, $\mathrm{Cs}_{2} \mathrm{LiYCl}_{6}: \mathrm{Ce}(\mathrm{CLYC})^{22}$ および $\mathrm{Cs}_{2} \mathrm{LiLaBr}_{6}: \mathrm{Ce}$ $(\mathrm{CLLB})^{23,24)}$ などは, 発光量がそれぞれ20,000および 60,000 フォトン/MeV以上と, Ce:LiCAFに比べて数倍以 上の発光量を持つ。さらに，ガンマ線にたいしてもエネ ルギー分解能が非常によく, 中性子計測においてノイズ となるガンマ線の分別能力も高い. 一方で, これらの塩 化物や臭化物シンチレーターの蛍光寿命は, 短寿命であ るが, 遅発成分も存在し, 全体的には数マイクロ秒程度 以上の蛍光寿命を有するものもある。そのため，熱中性 子のTOF弁別計測は不向きであるとの指摘がある。さら に，潮解性があることから，結晶育成およびパッケージ 技術などの加工の困難性や経年劣化しやすいなどの課 題，またコストがかかるなどの課題を抱えている。

熱中性子のTOF弁別計測には ${ }^{6} \mathrm{Li}{ }^{10} \mathrm{~B} か ゙$ 添加された高 速シンチレーターが有効である。TOF弁別を必要としな い最も簡単な画像計測としてはイメージングプレートに

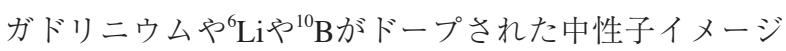
ングプレートが市販されており ${ }^{25)}$, 高感度に熱中性子画 像を計測することができる。この手法は大面積の測定が 比較的容易であるという利点を有する。 
シンチレーションをもちいたアクティブ検出器以外に 金属䈃の中性子との反応による放射能を計測するいわゆ る放射化法が広く中性子計測に用いられる。熱中性子の 計測では，金，インジウム，デイスプロシウム等が使わ れる ${ }^{26)}$ 。これらは中性子照射した後に，放射化反応で生 成した各種の崩壊に伴い放出するガンマ線をゲルマニウ ム検出器で計測する。その他放射化箔をフィルムあるい はイメージングプレートに密着させて一定時間感光し, スキャンする中性子イメージング計測がある。最後に Table 1 に熱中性子測定に利用される元素, 素子につい てその特性を示す。それらを利用した，実際に使用され ている検出器の空間分解能を最後に示す.

\section{3. エピサーマルから中速中性子計測技術}

熱中性子 $(0.5 \mathrm{eV})$ 以上から $100 \mathrm{eV}$ 領域をエピサーマル (熱外)中性子や低速中性子と呼び, $100 \mathrm{eV}-100 \mathrm{keV}$ 中 速中性子とここでは呼ぶ. BNCT治療では深くの腫瘍 まで中性子を届ける必要があることから，0.5 eVから $10 \mathrm{keV}$ の中性子が重要視される。 また多くの中性子共鳴 吸収がこれらのエネルギー領域に存在するため応用研究 が多い.この領域での中性子計測は基本的に熱中性子と 同じく， ${ }^{3} \mathrm{He}$ 比例計数管や，放射化法が用いられる。多 くの放射化材が熱中性子領域に感度が高いため, 熱外中 性子はポリエチレンなど減速材を用いて減速させてから 検出することが多い. 熱中性子と区別して計測する必要 がある場合は，カドミウムなど熱中性子を吸収する物質 で取り囲んだ比例計数管を用いることがある，有機シン チレーターの場合, 中性子-水素反跳の断面積は大きい が, 反跳陽子のエネルギーが小さいため，1個の中性子 信号は非常に小さな電流值となり, 一般に検出が困難で ある。

エピサーマル領域では共鳴吸収が多数存在し，これら は元素によって異なる. Fig. 2 はJENDLデータベース ${ }^{8)}$ から，いくつかの核種の中性子共鳴ピークを比較したも のである。他にも，P. Schillebeeckxらのまとめ ${ }^{27)}$ が参考 になる。レーザー駆動中性子源など短パルス性にすぐれ た中性子源があり，そのエネルギースペクトルが連続的 である場合, 時間分解計測によって中性子エネルギー が特定できるため, 元素の非破壊による特定が可能 である。この技術はNeutron Resonance Capture Analysis

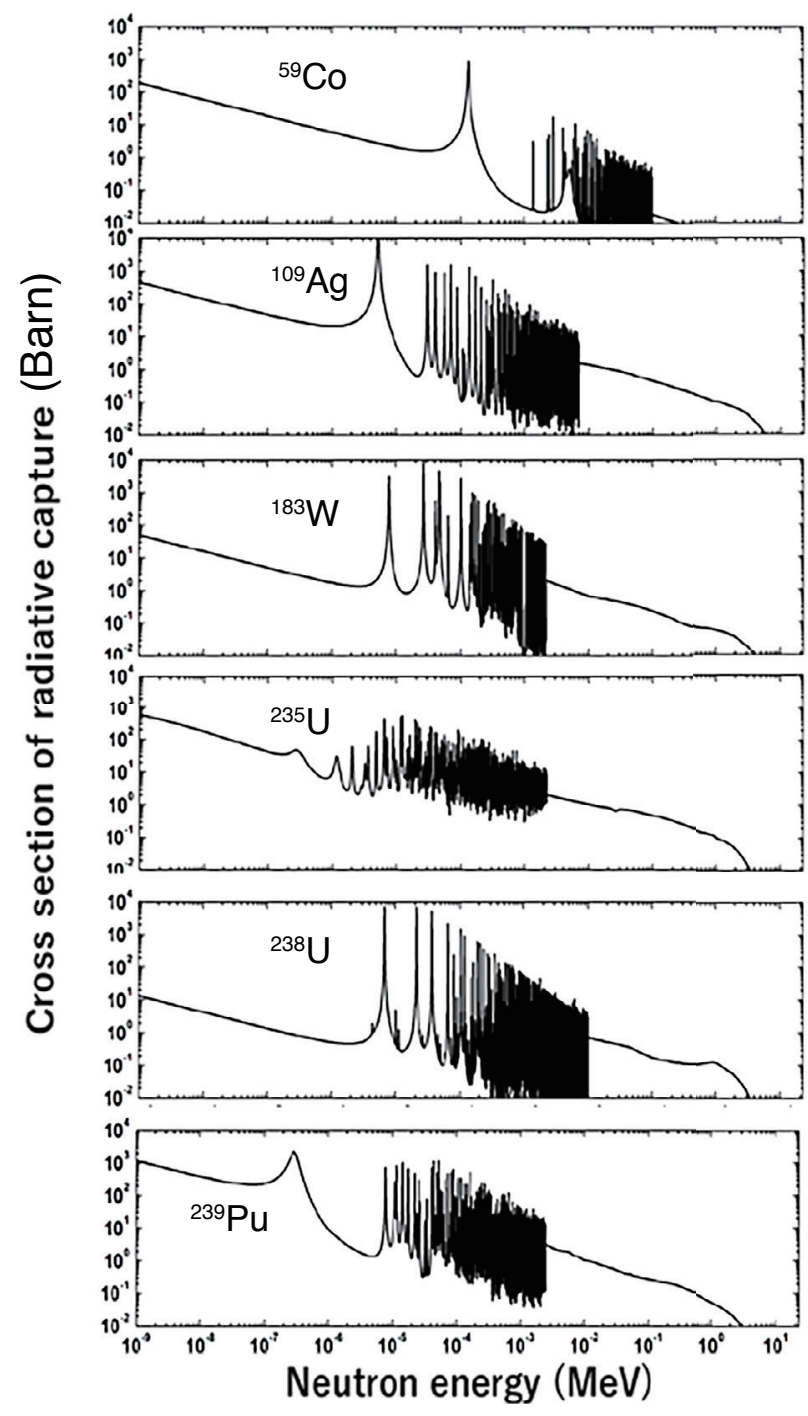

Fig. 2 Neutron absorption resonances for various nucluear.

(NRCA) や Neutron Resonance Transmission Analysis (NRTA)としてしられる ${ }^{28)}$ ，パルス幅がピコ秒にできる レーザー駆動中性子源は, 時間分解能に優れた飛行時間 弁別計測が可能になるため, エネルギー分解能の高い分 析が可能となるため, 今後の研究展開が期待されてい る.

Table 1 The comparisons of the thermal neutron detection methods.

\begin{tabular}{|c|c|c|c|c|c|c|}
\hline Element & ${ }^{3} \mathrm{He}$ & & ${ }^{6} \mathbf{L i}$ & & ${ }^{10} \mathbf{B}$ & $\mathrm{Au}, \mathrm{In}, \mathrm{Dy}$ \\
\hline Device & ${ }^{3} \mathrm{He}$ gas & $\mathrm{LiF} / \mathrm{ZnS}(\mathrm{Ag})$ & Li glass sctintillator & $\begin{array}{l}\text { Crystals such } \\
\text { as Ce:LiCAF }\end{array}$ & $\begin{array}{l}{ }^{10} \mathrm{~B} \text { doped } \\
\text { materials }\end{array}$ & $\begin{array}{c}\text { Nuclear activation } \\
\text { metals }\end{array}$ \\
\hline $\begin{array}{l}\text { Sentitivity } \\
\text { (for thermal } \\
\text { neutron) }\end{array}$ & $\sim 100 \%$ & $\sim 100 \%$ & $\sim 100 \%$ & $\sim 100 \%$ & $\sim 100 \%$ & $\sim 100 \%$ \\
\hline $\begin{array}{c}\text { Time } \\
\text { resolution }\end{array}$ & $\sim 1 \mu \mathrm{s}$ & & $\begin{array}{c}\text { about } 60 \mathrm{~ns} \\
\text { (APLF80: } 5 \mathrm{~ns} \text { ) }\end{array}$ & $\sim 20 \mathrm{~ns}$ & $\sim$ few $10 \mathrm{~ns}$ & Time integrated \\
\hline $\begin{array}{l}\text { Spatial } \\
\text { resolution }\end{array}$ & $\begin{array}{l}100 \mu \mathrm{m}: \\
\text { for MWPC } \\
\text { or } \mu \text {-PIC }\end{array}$ & $\begin{array}{l}\sim 200 \mu \mathrm{m}: \text { Cou- } \\
\text { pled with CCD }\end{array}$ & $\begin{array}{r}\sim 200 \mu \mathrm{m}\left(\text { for }{ }^{6} \mathrm{Li}\right. \\
\text { coupled with } \mathrm{CCD} \\
\text { multi anode }\end{array}$ & $\begin{array}{l}\text { scintillator } \\
, \sim 1 \mathrm{~mm} \text { (for } \\
\text { PMT) }\end{array}$ & $\begin{array}{c}55 \mu \mathrm{m} \text { (B dope } \\
\text { MCP) }\end{array}$ & $\begin{array}{l}\sim 100 \mu \mathrm{m} \text { (for activation } \\
\text { foil coupled with Imag- } \\
\text { ing Plate) }\end{array}$ \\
\hline
\end{tabular}


Table 2 The comparisons of the epi-thermal neutron detection methods.

\begin{tabular}{ccccc}
\hline Method & $\begin{array}{c}\text { Nuclear activation } \\
\text { with moderator }\end{array}$ & $\begin{array}{c}\text { Nuclear activation } \\
\text { without moderator }\end{array}$ & Plastic scintillator & Ce:LiCAF \\
\hline $\begin{array}{c}\text { Sensitivity, (for } \\
\mathbf{1 ~ k e V ~ n e u t r o n )}\end{array}$ & $\begin{array}{c}\text { about } 1 \% . \\
\text { (determined by losses } \\
\text { in neutron moderator) }\end{array}$ & $\begin{array}{c}\text { about } 1 \% \text { for } 1 \mathrm{~mm} \\
\text { thick Silber (cross } \\
\text { section of material) }\end{array}$ & $\begin{array}{c}\text { about } 1 \% \\
\text { (about 10 couts of neu- } \\
\text { tron-hydrogen recoil) }\end{array}$ & 0.1\% for a count \\
\hline Spacial resolution & $\begin{array}{c}\text { Several hundreds of } \\
\text { micron by using } \\
\text { imaging plate }\end{array}$ & $\begin{array}{c}\text { Several hundreds of } \\
\text { micron by using } \\
\text { imaging plate }\end{array}$ & $\begin{array}{c}\sim 1 \mathrm{~mm}, \\
\text { (detemined by pixel size of } \\
\text { scintillator array) }\end{array}$ & $\begin{array}{c}\text { (determined by pixel } \\
\text { size of scintillator array) }\end{array}$ \\
\hline Time resolution & $\begin{array}{c}\text { Time integrated } \\
\text { (life time of the } \\
\text { activation nuclear) }\end{array}$ & $\begin{array}{c}\text { Time integrated } \\
\text { (life time of the } \\
\text { activation nuclear) }\end{array}$ & $\begin{array}{c}\sim 2 \mathrm{~ns} \\
\text { (decay time of scintillator) }\end{array}$ & $\begin{array}{c}\text { (decay time of } \\
\text { scintillator) }\end{array}$ \\
\hline
\end{tabular}

\section{4. 高速中性子計測技術}

\section{1 高速中性子計測用シンチレーター}

一般に0.1 MeV以上の中性子を高速中性子と呼ぶ. Fig. 1 に示すように, $1 \mathrm{MeV}$ 超えるエネルギーの中性 子計測には, 水素の反跳反応の断面積が比較的高いた め，水素含有率の多い有機材料が用いられ，プラスチッ クや液体性のシンチレーターが一般的に用いられる。 $1 \mathrm{MeV}$ の中性子に対して, プラスチック内で水素と反跳 する確率はおよそ $10 \% / \mathrm{cm}$ であるから, 高感度検出のた めには5 $-10 \mathrm{~cm}$ 程度の厚さが必要とされる，有機シンチ レーターはポリビニルトルエンなどのポリマーに“PPO” や“bisMSB”といった有機色素が添加された構造をして おり, これら有機色素のシンチレーション発光減衰時定 数は一般的に1-2 nsと高速応答である.

一方, 発光効率は無機結晶シンチレーター (Ce:LiCAF など)が有機シンチレーターは〜1000 フォトン1中性子 リコイルあたりの光信号では十分な電気信号をとらえる のは無機シンチレーターにくらべて困難になる.

Fig. 3 に典型的な高速中性子計測器の設計例を示す. このようにシンチレーターを光電子増倍管にオプティカ ルマッチンググリス等で接着させて計測する場合は1中 性子の検出は可能となる. 中性子の検出効率を $50 \%$ 程度 にするため，シンチレーターの厚さを $10 \mathrm{~cm}$ 程度にする 設計がほとんどである。一方で, Fig. 4 に示すように, 中性子画像計測器の場合はシンチレーターピクセルパネ ルとイメージインテンシファイアカメラからなる装置が 一般的である。一般的にシンチレーターパネルの光が微 弱なため, イメージングインテンシファイアカメラに よって光を増倍させCCDで計測する.イメージインテ ンシファイアは, 光電面によって光電変換された電子を マイクロチャンネルプレート (MCP)によって増倍し,

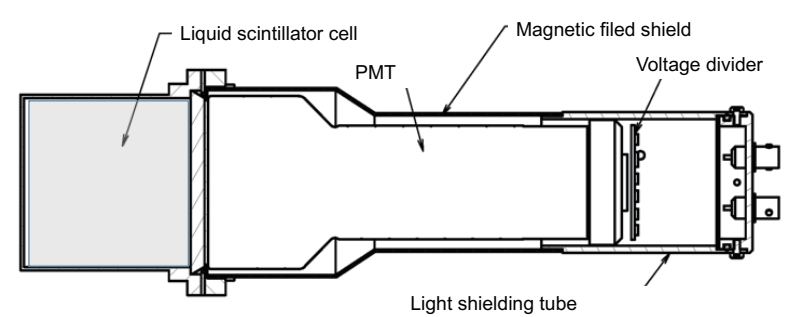

Fig. 3 Structure of the fast neutron scintillation detector.

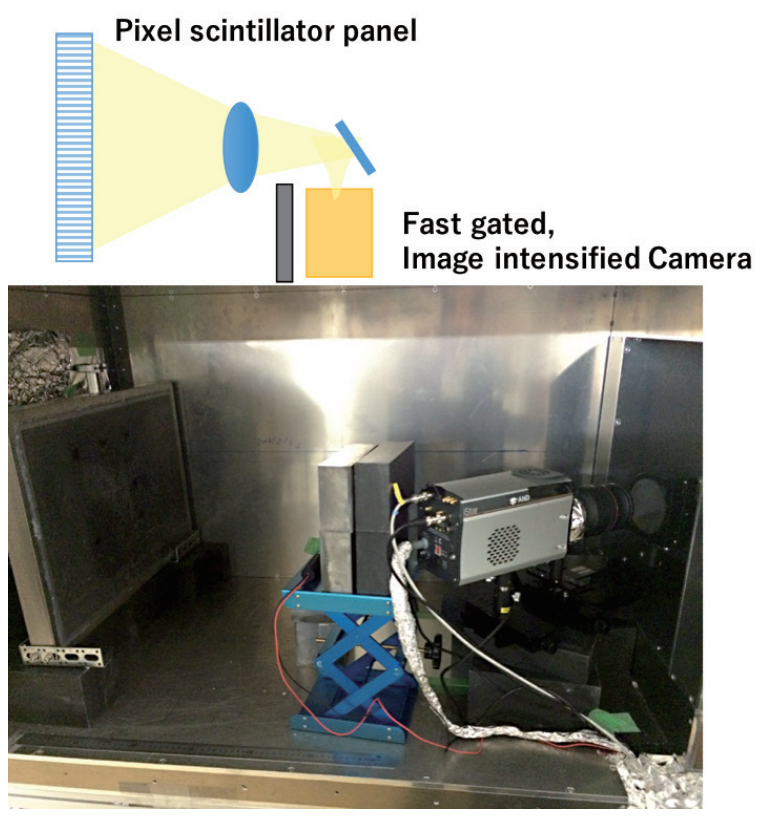

Fig. 4 Experimental setup of the fast neutron imaging detector.

それを蛍光体に衝突させ増強された画像をCCDで撮像 する。イメージインテンシファイアの受光面サイズは一 般的なもので $2 \mathrm{~cm}$ 程度, 特殊なものでも $10 \mathrm{~cm}$ が最大で あり，いずれも非常に高価である。シンチレーターア レーは中性子検出感度を高めるため数センチの厚さが必 要になるが，空間分解能は小さい方が望ましい，そのた めシンチレーターピクセルは厚さ数センチ, 細さは $1 \mathrm{~mm}$ 程度(製作技術の限界)のものが多数並んだものが 利用される. Fig. 5(a)のようにプラスチックシンチレー ターファイバを配列したものが市販されてはいるが，製 作費用が高価になり大型化は困難であった．Fig. 5(b)は 最近開発され液体シンチレーターをアルミハニカムパネ ルに浸して, ガラスで封じ込めたものである ${ }^{29)}$. プラス チックシンチレーターファイバより細かい分解能と高感 度を維持しつつ, 圧倒的な低価格を実現し, メートルサ イズでも容易に作れるようになった。プラスチックシン チレーターも液体シンチレーターも中性子1 リコイルあ たりでシンチレーターの発光量は1000 フォトン程度で あるが, シンチレーターファイバ内を伝送する間にロス が発生し，表面までたどり着けるのはおよそ10\%程度に 
(a)

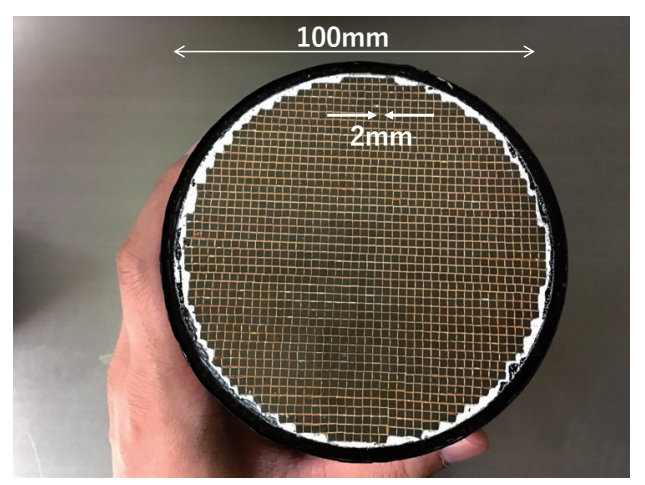

(b)

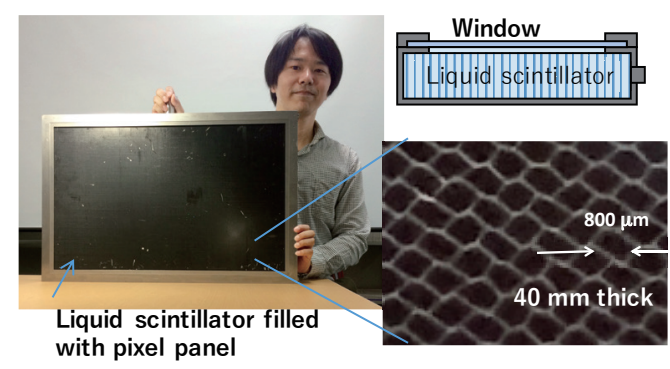

Fig. 5 (a) Plastic scnitillator pixel array(Saint Gobain), and (b) Liquid scintillator based pixel panel.

なってしまう。また $10 \mathrm{~cm}$ 以上の画角のシンチレーター アレー面の発光パタンをレンズ等で縮小してイメージイ ンテンシファイアカメラの受光面 $(2 \mathrm{~cm}$ 程度)まで伝送す るときの光伝送効率は, $\mathrm{F}$ 值 $=1$ の非常に光収率の良い レンズを使ったとしても $0.01 \%$ 程度であるので，1中性 子検出あたり中性子画像検出装置に到達できるフォトン の数は1個以下になってしまう。このため, 高速中性子 画像計測は一般的に非常に感度が低く, 実用的な画像を 取得するためには, 各ピクセルに数千個中性子が入射

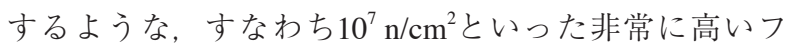
ラックスの中性子ビームが必要となる. Fig. 6 に示すの は, 理化学研究所RANSを用いて高速中性子フラックス $10^{6} \mathrm{n} / \mathrm{cm}^{2}$ 発生させ, Fig. 5 の液体シンチレーターピク セルパネルの手前に被写体としてコンクリートブロック と水を設置し，1000秒間の画像することで得られた画像 である，液体シンチレーターの感度は高速中性子に高 く, 熱中性子には感度が低い(反応断面積は同程度であ るが，1中性子検出に対する発光フォトン数は中性子エ ネルギーに比例するため, $1 \mathrm{MeV}$ 中性子と $0.025 \mathrm{eV}$ 中性 子で $4 \times 10^{7}$ の信号強度差)ことから，この画像は主に高 速中性子によるものであると推定される。しかしなが

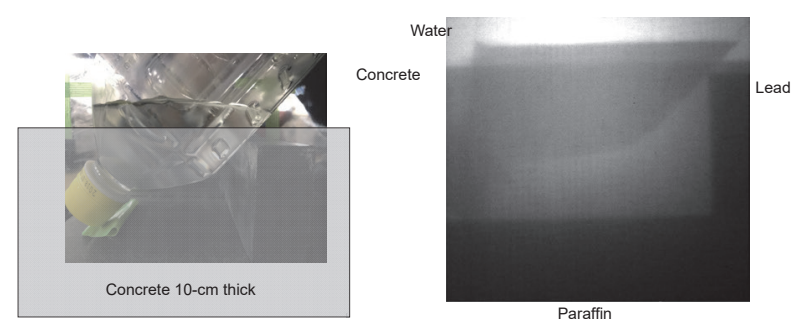

Fig. 6 Fast neutron radiograph image of the water behind the $10-\mathrm{cm}$ thick concrete.
ら，この実験ではガンマ線と中性子は弁別できておら ず，ガンマ線と中性子の混合画像である。モンテカルロ シミュレーション計算を用いて加速器から発生する中性 子とガンマ線を模擬し，この画像に混入したガンマ線の 割合を推定した，水・パラフィン・鉛の影の濃さについ て，中性子とガンマ線の混合比を50\%：50\%にした場合 に実験デー夕に近い画像が再現できたことから，高速中 性子とガンマ線50\%：50\%程度の混合画像であると推定 している。この画像では $10 \mathrm{~cm}$ 厚のコンクリートは透け て見えており，その背面にペットボトルに入った水があ ることが鮮明にわかる。この実験によって高速中性子に よるラジオグラフがコンクリート壁やコンクリート橋の 中に雨水がたまり，崩壊の危険性があるものを非破壊で 検査することができることが証明された。

\section{2 シンチレーター以外の高速中性子計測法}

シンチレーターは感度に優れてはいるが，ガンマ線と 中性子の弁別が問題になる場合がある，高速中性子に感 度の高い放射材料がいくつかあり，レーザー核融合中性 子の計測などで広く用いられている30). 計測手法は熱中 性子のそれと同様である。飛跡検出器はCR-39 と呼ばれ るプラスチックが一般的に用いられ，高速中性子が入射 すると陽子を反跳する原理を用いている ${ }^{32)}$ 。この手法は 電子やX線には感度がなく，他のイオン粒子も1枚目に 金属フィル夕を入れるなどして止めることできるため, 中性子のみを検出したい場合に効力を発揮する。その陽 子がCR-39のポリマー鎖を切断する。 そのダメージが 入ったCR-39を強アルカリ水溶液でエッチングすると, ダメージ穴が数ミクロンまで大きくえぐられた状態にな り，顕微鏡を用いれは観察できるようになる，検出効率 はCR-39の厚さで決定され, 中性子と陽子の衝突断面積 はプラスチックシンチレーターのそれとほぼ同じ断面積 である. CR-39の厚さは反跳陽子の平均自由行程以下と しなければならない。跳陽子がCR-39内で止まってし まった場合，CR-39の内部にできたダメージはエッチン グされないため検出することが不可能であるからであ る. 例えば2 $\mathrm{MeV}$ の中性子の反跳で発生する最大エネル ギー2 MeVの陽子が貫通できるCR-39の厚さがおよ そ100 $\mu \mathrm{m}$ である. 1 枚のCR-39厚さ $0.1 \mathrm{~mm}$ の場合 $0.1 \% の$ 検出効率しかないので, 通常は10枚程度重ねて合計

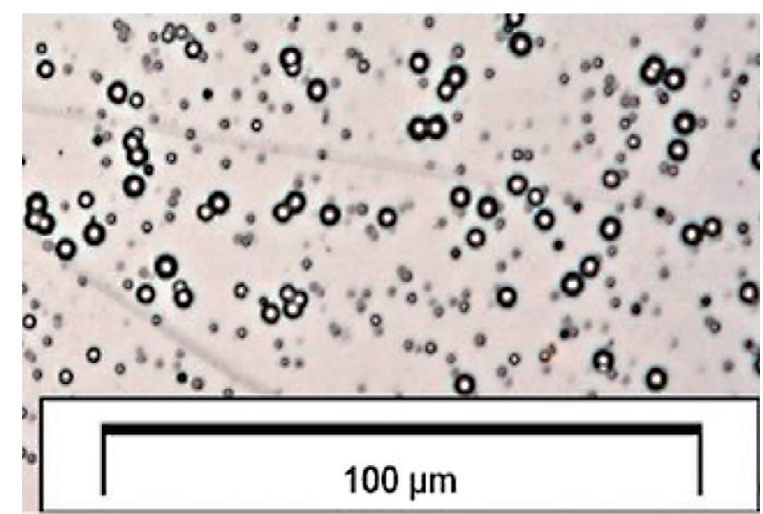

Fig. 7 CR-39 etch pits of the proton. 
で1\%の検出効率として使用する。しかしエッチングに は化学実験設備と, 作業時間がかかる(例えば水酸化力 リウ $46 \mathrm{~mol} / \mathrm{L}, 70^{\circ} \mathrm{C}$ ，数時間エッチングでようやく ピット解析ができる)ため, 中性子線照射実験のその場 で解析することは困難な技術である。実質的には $10^{4} /$ $\mathrm{cm}^{2}$ 程度の中性子が入射しすれば解析できる信号にな る.

バブル検出器 ${ }^{32}$ は有機性ゲル材の中に有機材料の液滴 が拡散されており，その液滴は常温では過飽和状態に なっている. 中性子が液滴に衝突すると反跳粒子を生成 し，それらのイオンは液滴内でエネルギーを落として， その熱で液滴は気体になり泡となる。 バブル検出器もX 線や他のイオンに感度を持たず, 中性子のみを検出した い場合に有効である。Fig. 8 の写真のように目視できる ようになるため，その場で中性子を観測できる優れた ツールである。中性子が液滴に衝突してから泡ができる までの時間が1秒程度かかるため, 高速時間分解はでき ない，エネルギー閾值があり，閾值以下のエネルギーで は泡が出来ない構造になっている. 検出効率は典型的 に $10^{4} / \mathrm{cm}^{2}$ で1 カウント程度であるため $10^{5} / \mathrm{cm}^{2}$ 程度から実 用的な計測ができるようになる。泡ができても加圧によ り泡を潰して再利用できるため, 非常に便利な計測ツー ルである。 バブル検出器にはいくつかエネルギー感度が 違う種類があり, $\mathrm{keV}$ 領域から $10 \mathrm{MeV}$ 領域まで非常に広 いエネルギーをカバーすることができる. Fig. $8^{33)}$ に示 すように, BDS-10は10 keV以上で感度があることを示 し, BDS-10000は10000 keV以上で感度があることを示 す。ガンマ線に対してはほほ感度がないことを示 すため，著者らが行った実験によると，1.17 MeVと $1.33 \mathrm{MeV}$ のコバルト 60 ガンマ線に対して, $10^{13} / \mathrm{cm}^{2}$ のガ ンマ線入射に対してもバブルは1個も検出されなかっ た。著者らはバブル検出器をシート状にしたものを開発 しており，それを用いれば中性子画像計測も可能であ る。 バブル検出器は簡易で, ガンマ線には感度がなく, 熱中性子への感度が小さく, リアルタイムに可視化でき る, 加圧によって泡を潰すと再利用できることから, 中 性子計測の強力なツールである。最後に高速中性子計測 手法の特徵をTable 3 に比較する. (a)
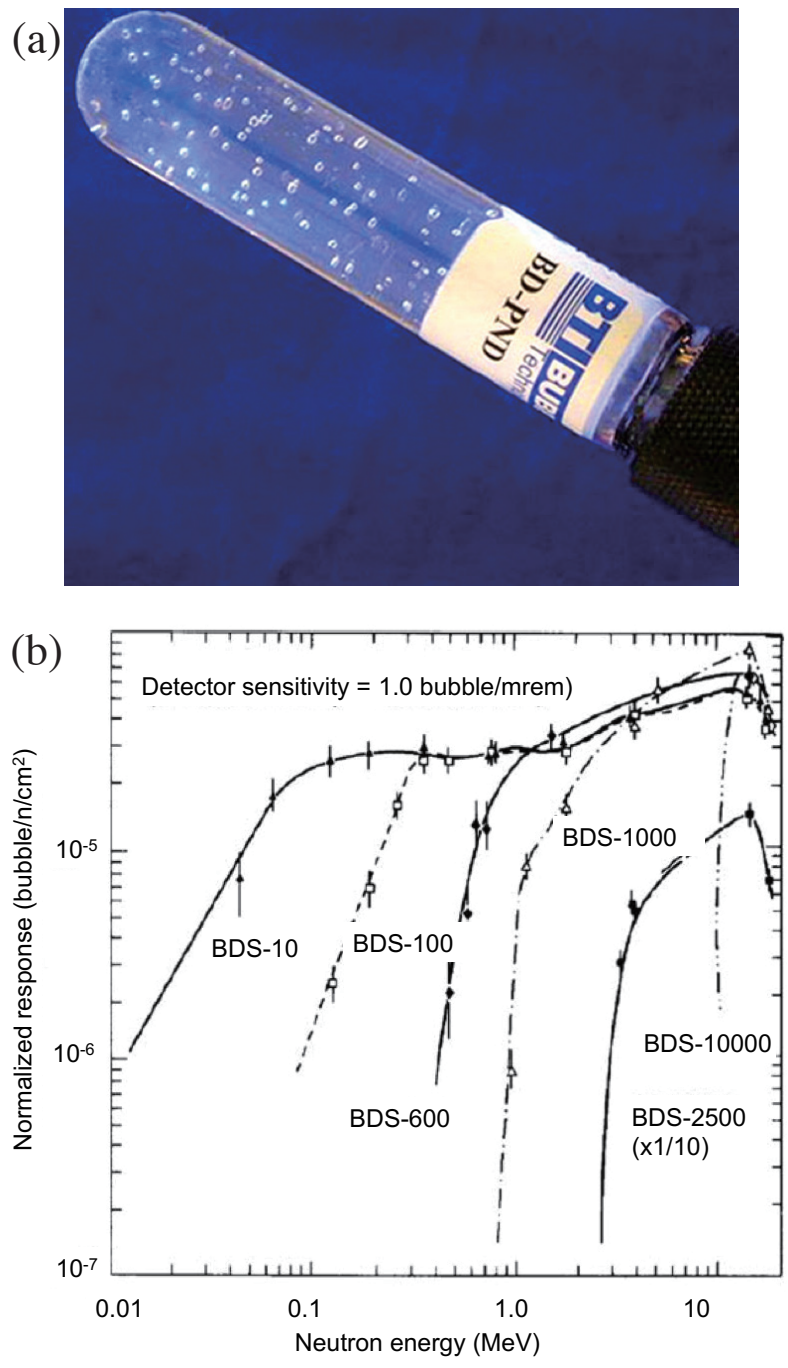

Fig. 8 (a) Bubble detector photo and (b) the sensitivity. ${ }^{33)}$

\section{5. まとめと今後の展望}

本稿ではエネルギーに分けて中性子の検出方法, 画像 計測手法をレビューしてきた。中性子はエネルギー領域 や用途に応じて適切な原理手法を用いることが重要であ る。モデレーターを使って全てを熱中性子に減速してし まって計測する手法を除いて，一つの手法で熱中性子か ら高速中性子まですべてを高感度に検出することは困難 である。熱中性子領域は比較的薄い素子で中性子の検出

Table 3 The comparisons of the fast neutron detection methods.

\begin{tabular}{ccccc}
\hline Methods & Plastic/Liquid Scintillator & CR-39 & Bubble dtectors & Nuclear activation \\
\hline $\begin{array}{c}\text { Sensitivity } \\
\text { (for 1 MeV } \\
\text { neutrons) }\end{array}$ & $\begin{array}{c}\sim 10 \% \text { detection efficienc.Single-hit } \\
\text { detector can measure a neutron, } \\
\text { neutron imaging detector require } \\
100 \text { counts per pixel }\end{array}$ & $\begin{array}{c}0.1 \% \\
\text { (for 100 } \mu \mathrm{m} \text { thichness } \\
\text { CR-39) }\end{array}$ & $\begin{array}{c}0.01 \% \text { for a bubble } \\
\text { detector }\end{array}$ & $\begin{array}{c}\text { About } 1 \% \text { for } 1 \mathrm{~mm} \\
\text { thick nuclear activation } \\
\text { material }\end{array}$ \\
\hline $\begin{array}{c}\text { Spatial } \\
\text { resolution }\end{array}$ & $\begin{array}{c}\text { several hundreds of micron (de- } \\
\text { temined by pixel size of scintillator } \\
\text { array) }\end{array}$ & $\begin{array}{c}\text { Several hundreds of } \\
\text { micron (for } 100 \mu \mathrm{m} \\
\text { thichness CR-39) }\end{array}$ & $\begin{array}{c}\text { Few mm } \\
\text { (bubble size) }\end{array}$ & $\begin{array}{c}\text { Several hundreds of } \\
\text { micron by using imag- } \\
\text { ing plate }\end{array}$ \\
\hline $\begin{array}{c}\text { Time } \\
\text { resolution }\end{array}$ & $\begin{array}{c}\text { Time integrated } \\
\text { (ecthing time is } \sim \\
\text { several hours) }\end{array}$ & $\begin{array}{c}\text { about 10 ms } \\
\text { (detemined by time for } \\
\text { bubble creation) }\end{array}$ & $\begin{array}{c}\text { Time integrated } \\
\text { (life time of the activa- } \\
\text { tion nuclear) }\end{array}$ \\
\hline
\end{tabular}


が可能であり，すでに満足な感度が得られている，市販 品も普及しており, 応用研究も多い. 高速中性子はここ で述べた手法が代表的であり，まだまだ感度が足りない のが現状である。中性子の検出効率は中性子-陽子の反 応断面積で決まっており，大幅に向上させることは不可 能であるため, 今後の課題はシンチレーション光をいか に高感度に検出できるか, すなわち光検出デバイスの開 発が求めらている. 現状は高価なイメージインテンシ ファイアが用いられているが，よりコンパクトで安価な デバイスが開発されることで, 高速中性子の応用が広が ると期待される。

\section{謝 辞}

本研究の一部は,科学技術振興機構研究成果最適展開 支援プログラムA-STEPコンパクト中性子源とその産業 応用に向けた基盤技術の構築の支援を受けました。

\section{参考文献}

1) Y. Ikeda, A. Taketani, M. Takamura, H. Sunaga, M. Kumagai, Y. Oba, Y. Otake, and H. Suzuki: Nucl. Instr. Meth. A. 833 (2016) 61

2) M. Roth, D. Jung, K. Falk, N. Guler, O. Deppert, M. Devlin, A. Favalli, J. Fernandez, D. Gautier, M. Geissel, et al.: Phys. Rev. Lett. 110 (2013) 044802, 24

3) J. Alvarez, J. Fernández-Tobias, K. Mima, S. Nakai, S. Kar, Y. Kato, and J. M. Perlado: Physics Procedia 60 (2014) 29.

4) Von der Hardt Heinz Rottger: Neutron Radiography Handbook: Nuclear Science and Technology (Springer Science \& Business Media, 2012).

5) H. Rauch and D. Petrascheck: Dynamical neutron diffraction and its application (Topics in Current Physics V. 6 Springer; Berlin, Germany, F. R., 1978).

6) K. Kaneko, T. Kamiyama, Y. Kiyanagi, T. Sakuma, and S. Ikeda: Journal of Physics and Chemistry of Solids 60 (1999) 1499.

7) H. Hatanaka: Radiology and Nuclear Medicine (Kluwer Academic Publishers; Norwell, MA USA, 1987).

8) K. Shibata, O. Iwamoto, T. Nakagawa, N. Iwamoto, A. Ichihara, S. Kunieda, S. Chiba, K. Furutaka, N. Otuka, T. Ohsawa, et al.: J. Nucl. Sci. Technol. 48 (2011) 1.

9) M. Manolopoulou, M. Fragopoulou, S. Stoulos, E. Vagena, W. Westmeier, and M. Zamani: J. Phys. Conf. Ser. 366 (2012) 012033.

10) A. Oed: Nucl. Instrum. Meth. Phys. Res., A 471 (2001) 109

11) S. Uno, T. Uchida, M. Sekimoto, T. Murakami, K. Miyama, M. Shoji, E. Nakano, T. Koike, K. Morita, H. Satoh, et al.: Phys. Proc. 26 (2012) 142.

11) J. D. Parker, M. Harada, K. Hattori, S. Iwaki, S. Kabuki, Y. Kishimoto, H. Kubo, S. Kurosawa, Y. Matsuoka, K. Miuchi, et al: Nucl. Instr. Meth. A 726 (2013) 155.

12) T. Fujiwara: AIST Bulletin Metrology 9 (2018) p. 439.

12) M. Köhli, M. Klein, F. Allmendinger, A.-K. Perrevoort, T. Schr öder, N. Martin, C. J. Schmidt, and U. Schmidt: J. Phys. Conf. Ser. 746 (2016) 012003.

13) A. S. Tremsin, J. V. Vallerga, J. B. McPhate, O. H. W. Siegmund, and R. Raffanti: IEEE Trans. Nucl. Sci. 60 (2013) 578.

14) K. Nittoh, C. Konagai, T. Noji, and K. Miyabe: Nucl. Instr. Meth. Phys. Res. A 605 (2009) 107.

15) K. Wilhelm, J. Nattress, and I. Jovanovic: Nucl. Instrum. Meth. Phys. Res. A 842 (2017) 54.

16) T. Yanagida, A. Yoshikawa, Y. Yokota, K. Kamada, Y. Usuki, S. Yamamoto, M. Miyake, M. Baba, K. Kumagai, and K. Sasaki: IEEE Trans. Nucl. Sci. 57 (2010) 1492.

17) K. Hirota, T. Shinohara, K. Ikeda, K. Mishima, T. Adachi, T Morishima, S. Satoh, T. Oku, S. Yamada, H. Sasao, et al.: Phys. Chem. Chem. Phys. 7 (2005) 1836.

18) A. Gektin, N. Shiran, S. Neicheva, V. Gavrilyuk, A. Bensalah, T. Fukuda, and K. Shimamura: Nucl. Instrum. Meth. Phys. Res. A 486 (2002) 274

19) Y. Kiyanagi, T. Kamiyama, K. Kino, H. Sato, S. Sato, and S.Uno: J. Instrumentation 9 (2014) C07012.

20) K. Takahashi, S. Tazaki, K. Neriishi, and M. Etho: Fujifilm Reserch \& Development 43 (1998)

21) Y. Arikawa, K. Yamanoi, T. Nakazato, E. S. Estacio, T. Shimizu, N. Sarukura, M. Nakai, T. Norimatsu, H. Azechi, T. Murata, et al.: Rev. Sci. Instrum. 80 (2009) 113504.

22) C. M. Combes, P. Dorenbos, C. W. E. v. Eijk, K. W. Krmer, and H. U. Gdel: J. Luminescence 82 (1999) 299.

23) U. Shirwadkar, J. Glodo, E. V. D. van Loef, R. Hawrami, S. Mukhopadhyay, A. Churilov, W. M. Higgins, and K. S. Shah: Nucl. Instr. and Meth. A 652 (2011) 268

24) J. Glodo, E. V. D van Loef, R. Hawrami, W. M. Higgins, A. Churilov, U. Shirwadkar, and K. S. Shah: IEEE Trans. Nuc. Sci. 58 (2011) 333

25) Y. K. Haga, K. Neriishi, K. Takahashi, and N. Niimura: Nucl. Instrum. Meth. Phys. Res. A 487 (2002) 504

26) Z. B. Alfassi: Activation Analysis, Volumes I and II (CRC Press: Boca Raton, FL., 1990).

27) P. Schillebeeckx, B. Becker, H. Harada, and S. Kopecky: JRC Science and Policy Reports (European commission, 2014).

28) C. Paradela, J. Heyse, S. Kopecky, P. Schillebeeckx, H. Harada, F. Kitatani, M. Koizumi, and H. Tsuchiya: EPJ Web of Conf. 146 (2017) 09002

29) Y. Arikawa, S. Matsubara, Y. Abe, Y. Kato, H. Kishimoto, A. Yogo, H. Nishimura, M. Nakai, H. Shiraga, S. Fujioka, et al.: Proc. SPIE 10328 (2017) 103280T.

30) D. L. Bleuel, C. B. Yeamans, L. A. Bernstein, R. M. Bionta, J. A. Caggiano, D. T. Casey, G. W. Cooper, O. B. Drury, J. A. Frenje, and C. A. Hagmann: Rev. Sci. Instrum. 83 (2012) 10D313.

31) J. A. Frenje, C. K. Li, F. H. Séguin, D. G. Hicks, S. Kurebayashi, R. D. Petrasso, S. Roberts, V. Yu. Glebov, D. D. Meyerhofer, T. C. Sangster, et al: Rev. Sci. Instrum. 73 (2002) 2597.

32) B. J. Lewis, M. B. Smith, H. Ing, H. R. Andrews, R. Machrafi, L. Tomi, T. J. Matthews, L. Veloce, V. Shurshakov, I. Tchernykh, et al.: Radiation Protection Dosimetry 150 (2011) 1.

33) H. Ing, R. A. Noulty, and T. D. McLean: Radiat. Meas. 27(1997) 1. 